\title{
AN EXPLORATORY RESEARCH STUDY OF MARKETING STRATEGIES OF IDBI FEDERAL INSURANCE CO. LTD
}

\author{
Himanshi Goyal* Dr. Navneet Joshi** Sanjive Saxena \\ *PGDM(IB) Student, \\ **Professor, \\ **Associate Professor \\ Jagan Institute of Management Studies, sector-5 , New Delhi -110085
}

Article DOI: https://doi.org/10.36713/epra7098

DOI No: 10.36713/epra7098

\begin{abstract}
This paper is covers the exploratory research study on the marketing strategies of IDBI Federal Insurance, Company. In the Indian context, Insurance companies are playing a major role in the development of Indian economy. With the entry of many private players in the insurance industry, the competition has risen manifold and hence insurance companies are coming out with innovative marketing strategies to woo the customer. This was the reason for narrowing down the scope of the research work. The present paper is an exploratory research study on the marketing strategy of IDBI Federal Insurance Company. The paper seeks to address the following objectives (a) To determine the marketing strategies of IDBI Federal Life Insurance Co. Ltd (b) To determine the means and mechanism deployed by IDBI Federal Life Insurance Co. Ltd. Applying the marketing mix and to determine the effectiveness of the strategy and (c) to understand the reasons which provide competitive advantage to IDBI Federal Life Insurance Co. Ltd. The paper is developed on the basis of elementary primary and secondary data available in the Internet and other documents and journals. The design of the paper follows a structured approach. The literature review resulted in the generation of the research objectives. The primary data was collected by means of Google Forms and MS Excel was used for data analysis. Descriptive Statistics is used to arrive at the findings and interpretation. The findings indicate that the majority of the people seek insurance cover for the purpose of having risk cover and availing several benefits associated with the life insurance policies. Further, the findings indicate that there is a need to capitalize social media platform for generating awareness to drive the market growth.
\end{abstract}

KEY WORDS: IDBI, Insurance, Marketing, Policies, Strategies

\section{INTRODUCTION}

The insurance industry of India, is one of the industry which impacts the economic growth of the country. The government has permitted many of the private players to enter the insurance market and contribute to the economic growth. Hence, today the industry is at the cross roads due to the fact that CORONA has shrunk the economy and also, many of the people see insurance as a well-planned strategy to avail the tax benefit rather than view insurance as a means and mechanism to provide assurance during the times of crisis. With the growth of the insurance industry, a need was felt to regulate the functioning of the Insurance companies, hence IRDAI was formulated to provide a systematic functioning of the insurance companies and hence many of the insurance companies began to focus on the marketing strategies to beat the competitors. With the growth of the insurance sector, several new areas and avenues began to come up. At present, the insurance industry of India consists of 63 insurance companies of which 24 cater to Life Insurance while 39 cater to non-life insurance such as car insurance, marine insurance, house insurance and the like. Further, there is also division in terms of public sector and private sector insurance companies. 


\section{LITERATURE REVIEW}

The market penetration is the most important index for the government as well as for the private sector insurance companies. This is on account of the fact that several projections and launch of several new insurance products are carried out with the help of understanding of the market size.

The following highlights the glimpse of the market size in the Indian context. On the basis of which several marketing strategies are devised by the insurance companies.

- Government's policy of insuring the uninsured has gradually pushed insurance penetration in the country and proliferation of insurance schemes.

- Gross premiums written in India reached Rs 5.53 trillion (US\$ 94.48 billion) in FY18, with Rs 4.58 trillion (US\$ 71.1 billion) from life insurance and Rs 1.51 trillion (US\$ 23.38 billion) from non-life insurance. Overall insurance penetration (premiums as \% of GDP) in India reached 3.69 per cent in 2017 from 2.71 per cent in 2001 .

- In FY19 (up to Jan 2019), premium from new life insurance business increased 3.91 per cent year-on-year to Rs 1.59 trillion (US\$ 22.04 billion). In FY19 (up to Jan 2019), gross direct premiums of non-life insurers reached Rs 1.39 trillion (US\$ 19.28 billion), showing a year-onyear growth rate of 12.65 per cent.

An extant review of literature resulted in the existence of the following types of insurance provided by the various insurance companies and that separate means and mechanisms are deployed for carrying out marketing strategies.

\section{Life Insurance}

This is the insurance product wherein the company provides the insurance to the human being who is generally the policy holder. Also, the person can take the policy in the name of his child or any other family member provider the rules and regulations are met. The insurer pays the fixed amount of insurance at the time of death or at the expiry of the certain period. The insurance companies focus their marketing strategies towards highlighting the advantages and the perils associated with the threat to life

\section{Property Insurance}

This is the insurance product wherein the insurance is carried out in the name of the property. The terms and conditions of this insurance covers the various types of risk that are involved to the property in question. The marketing strategies of the insurance companies are targeted towards the happening of the risk due to unforeseen circumstances. The premium of this type of insurance is dependent on the extant of the risk cover as sought by the property holder.

\section{Marine Insurance}

This is the insurance which deals with the perils and the risk associated with the goods which are being transhipped by sea to far off places. The marketing strategies of the various companies are targeted to the perils of travelling through the sea. The premium is based on the type of the ship, the route taken, the goods being transported and other factors such as weather as all these are the contributors to the risk coverage.

\section{Fire Insurance}

This is the insurance which is provided by the companies in dealing with the risk associated with the losses on account of fire. The marketing strategy of the insurance companies deals with the aspects of the losses arising out the happening of fire in the premises or any other building for which the insurance is sought. The premium is based on several factors such as the design of the premises, the type of the premises such as commercial, residential and the like.

\section{Car Insurance}

This is the insurance which is provided to the holder of the car. This is similar to property insurance except that the scope if small. The marketing strategy deployed by the companies include aspects such as the type of the car, the risks associated with the car while driving and the like. The amount of the premium is dependent on the aspects such as year of manufacturing, the type of registration of the car and the like.

\section{Research objectives}

The following are the research objectives which are arrived from the literature review

- To determine the marketing strategies of IDBI Federal Life Insurance Co. Ltd

- To determine the means and mechanism deployed by IDBI Federal Life Insurance Co. Ltd. Applying the marketing mix and to determine the effectiveness of the strategy

- To understand the reasons which provide competitive advantage to IDBI Federal Life Insurance Co. Ltd.

\section{RESEARCH METHODOLOGY}

The research methodology adopted in this research work included the blended work of grounded theory approach in the form of collection of primary data for determining and understanding the problem and consequently collecting the data.

The primary data was collected by means of questionnaire. The questionnaire was split into parts. One part collected the demographic information while the other part collected the responses of the 
respondents. The sample size was limited to the tune of 50 and the target respondents included the residents of Shahdara, Delhi. The data was collected by means of Google forms and MS Excel was deployed for the purpose of statistical analysis. Descriptive analysis was used in the process. The prime reason for using descriptive analysis was the fact that the secondary data was used more as compared to primary data.

The secondary data was collected by means of resources available in the internet and other documents.

\section{FINDINGS}

The marketing mix of IDBI Federal Life Insurance Co. Ltd. is the combination of marketing activities that it engages in so as to best meet the needs of its target market.
In the case of designing product portfolio or the product mix several aspects are taken into consideration namely child insurance, Group micro insurance, life insurance, term insurance and the like.

In order to increase the customer base and to improve the visibility in the market, IDBI Federal has around thousands and thousands of insurance agents all over India to manage their regional customers effectively. IDBI Federal has over 1201 branches all over India to cater to increasing customer base.

For pricing of the products, IDBI Federal Life Insurance Co. Ltd. provides various benefits to its customers such as Double tax benefit under section $80(\mathrm{C})$ and $10(10 \mathrm{D})$, bonus, terminal bonus, loyalty points and the like

For promotion and increasing the visibility IDBI Federal has also adopted various marketing strategies such as commercial advertising, Event conduction and the like.

\section{DATA ANALYSIS AND INTERPRETATION Personal Data}

- Marital Status:

\begin{tabular}{|c|c|}
\hline Options & Response \\
\hline Married & 75 \\
\hline Single & 25 \\
\hline
\end{tabular}

- Educational Qualification:

\begin{tabular}{|c|c|}
\hline Options & Response \\
\hline Illiterate & 10 \\
\hline School level & 15 \\
\hline College level & 35 \\
\hline Professional & 40 \\
\hline
\end{tabular}

- Occupation:

\begin{tabular}{|c|c|}
\hline Options & Response \\
\hline Govt. employee & 18 \\
\hline Private employee & 22 \\
\hline Business & 45 \\
\hline Others & 15 \\
\hline
\end{tabular}

- Family income:

\begin{tabular}{|c|c|}
\hline Options & Response \\
\hline$<2,00,000$ & 10 \\
\hline $2,00,000-4,00,000$ & 25 \\
\hline $4,00,000-6,00,000$ & 50 \\
\hline$>6,00,000$ & 15 \\
\hline
\end{tabular}

- $\quad$ State your level of awareness about life insurance.

\begin{tabular}{|c|c|}
\hline Options & Responses \\
\hline Very low & 2 \\
\hline Low & 3 \\
\hline Medium & 15 \\
\hline High & 40 \\
\hline Very High & 40 \\
\hline
\end{tabular}


- Rank your awareness about various insurance companies.(1-5)

\begin{tabular}{|c|c|c|c|c|c|}
\hline Options & 1 & 2 & 3 & 4 & 5 \\
\hline IDBI Federal & 40 & 20 & 18 & 12 & 10 \\
\hline SBI Life & 25 & 24 & 31 & 12 & 8 \\
\hline LIC & 58 & 22 & 10 & 8 & 2 \\
\hline HDFC & 15 & 15 & 32 & 18 & 20 \\
\hline ICICI & 20 & 20 & 18 & 30 & 12 \\
\hline
\end{tabular}

- How long you have been aware of life insurance policies?

\begin{tabular}{|c|c|}
\hline Options & Response \\
\hline$<5$ years & 10 \\
\hline $5-10$ years & 15 \\
\hline $10-15$ years & 20 \\
\hline$>15$ years & 55 \\
\hline
\end{tabular}

- What type of policies you are aware of? (multiple options)

\begin{tabular}{|c|c|}
\hline Options & Response \\
\hline Endowment & 80 \\
\hline Money back & 60 \\
\hline Children's plan & 40 \\
\hline Pension plan & 20 \\
\hline
\end{tabular}

- From which source you are aware of insurance companies?

\begin{tabular}{|c|c|}
\hline Options & Response \\
\hline Newspaper & 25 \\
\hline Television & 30 \\
\hline Agents & 20 \\
\hline Development officers & 5 \\
\hline Friends & 20 \\
\hline
\end{tabular}

- Which media attracted you for advertisements of life insurance companies? (1-5)

\begin{tabular}{|c|c|c|c|c|c|}
\hline Options & 1 & 2 & 3 & 4 & 5 \\
\hline Newspaper & 30 & 20 & 28 & 12 & 10 \\
\hline Magazine & 22 & 15 & 10 & 33 & 20 \\
\hline Posters & 5 & 12 & 20 & 28 & 35 \\
\hline Television & 35 & 37 & 8 & 12 & 8 \\
\hline Agents & 32 & 40 & 8 & 15 & 5 \\
\hline
\end{tabular}

- Do you know about IDBI Federal Life Insurance Co. Ltd.?

\begin{tabular}{|c|c|}
\hline Options & Response \\
\hline Yes & 73 \\
\hline No & 27 \\
\hline
\end{tabular}

- How did you know about IDBI Federal Life Insurance Co. Ltd.?

\begin{tabular}{|c|c|}
\hline Options & Response \\
\hline Printed media & 18 \\
\hline Television & 32 \\
\hline Agents & 18 \\
\hline Friends & 32 \\
\hline
\end{tabular}

- Do you feel these advertisements helps people to educate about their products?

\begin{tabular}{|c|c|}
\hline Options & Response \\
\hline Yes & 55 \\
\hline No & 45 \\
\hline
\end{tabular}


- What is the first thing that comes to your mind when you think/heard about IDBI Federal?

\begin{tabular}{|c|c|}
\hline Options & Response \\
\hline IDBI bank & 50 \\
\hline Logo & 10 \\
\hline Financial institute & 20 \\
\hline Insurance industry & 20 \\
\hline
\end{tabular}

- $\quad$ Are you aware about various products of IDBI Federal Life Insurance Co. Ltd.?

\begin{tabular}{|c|c|}
\hline Options & Response \\
\hline Yes & 50 \\
\hline No & 50 \\
\hline
\end{tabular}

- $\quad$ About how many products did you know? (multiple options)

\begin{tabular}{|c|c|}
\hline Options & Response \\
\hline Income insurance & 70 \\
\hline Wealth insurance & 80 \\
\hline Term plans & 150 \\
\hline Retirement plans & 50 \\
\hline Child plans & 100 \\
\hline Saving plans & 90 \\
\hline
\end{tabular}

- Do you have any policy with IDBI Federal Life Insurance Co. Ltd.?

\begin{tabular}{|c|c|}
\hline Options & Response \\
\hline Yes & 40 \\
\hline No & 60 \\
\hline
\end{tabular}

- If yes, what type of plan do you have? (multiple options)

\begin{tabular}{|c|l|}
\hline Options & Response \\
\hline Income insurance & 2 \\
\hline Wealth insurance & 15 \\
\hline Term plans & 25 \\
\hline Retirement plans & 3 \\
\hline Child plans & 30 \\
\hline Saving plans & 12 \\
\hline
\end{tabular}

- $\quad$ State the reason for taking the policy. (multiple options)

\begin{tabular}{|c|c|}
\hline Media & Response \\
\hline Savings & 60 \\
\hline Wide risk coverage & 30 \\
\hline Tax benefits & 81 \\
\hline Image and popularity of policy & 38 \\
\hline Known agent & 8 \\
\hline Fulfillment of future funds need & 85 \\
\hline
\end{tabular}

- What are the influencing factors of a company you consider before taking policies? (multiple options)

\begin{tabular}{|c|c|}
\hline Media & Response \\
\hline Reputation of company & 46 \\
\hline No. of branches & 19 \\
\hline Location & 35 \\
\hline Service quality & 90 \\
\hline Varity of products & 50 \\
\hline
\end{tabular}




\begin{tabular}{|c|c|}
\hline Assistance by agents & 76 \\
\hline Simple procedure \& formalities & 69 \\
\hline Amount of Risk Cover & 150 \\
\hline Maturity Sum Assured & 118 \\
\hline Premium Amount & 88 \\
\hline
\end{tabular}

\section{Final Interpretation}

According to the data collected, premium amount, maturity sum assured and amount of risk cover along with service quality with $12 \%, 16 \%$, $20 \%$ and $12 \%$ respectively are the most influencing factors for taking policy from IDBI Federal.

\section{Limitation}

The limitation that came out from the study is the small sample size. Had the sample size been large, more findings and new variables discovery would have provided a new direction to the research.

\section{CONCLUSION}

The marketing of IDBI Federal Insurance Co. is based on application of the basic principles of marketing theory. On a closer look it is observed that even despite of the tough competition it has been able to hold a good standing in the market on account of the fact that it has been constantly upgrading the processes and studying the market for lead generation. This is the key to sustaining the market.

\section{REFERENCES}

1. Acko, T. (2014, April). Types of insurance. Retrieved July 2019, from acko: https://www.acko.com/articles/generalinfo/types-of-insurancel

2. Alag, G. S. (2016). Business Studies. Premier Publication.

3. contributors, W. (2019, February 08). IDBI Federal Life Insurance. Retrieved July 2019, from wikipedia: https://en.wikipedia.org/wiki/IDBI_Federal_Life Insurance

4. Federa, T. I. (2014). About Us. Retrieved July 2019, from idbifederal.com: https://www.idbifederal.com/about-us/overview

5. Federal, T. I. (2014). Our Plans. Retrieved July 2019, from idbifederal.com: https://www.idbifederal.com/insuranceplans/retirement-solutions

6. IDBI Federal's competitors. (2019). Retrieved July 2019, from owler: https://www.owler.com/company/idbifederal

7. Indian insurance industry overview. (2019, July). Retrieved July 2019, from ibef: https://www.ibef.org/industry/insurance-sectorindia.aspx

8. Insurance industry in India. (2018, Januaury). Retrieved July 2019, from toppr: https://www.toppr.com/guides/generalawareness/capital-markets/insurance-industryin-indial
9. Mishra, A. (2014, August 04). Marketing mix \& Promotionl strategy of IDBI Federal. Retrieved July 2019, from SCRIBD: https://www.scribd.com/document/235820934/By -Adarsh-Mishra-Report-on-Marketing-MixPromotional-Strategies-at-IDBI-Federal-LfeInsurance-Final-Report

10. Poojary, V. (2013, April 03). Marketing 7p's of insurance. Retrieved July 2019, from scribd: https://www.scribd.com/doc/133761286/Marketin g-7-p-s-of-Insurance

11. Unknown. (2012, July 17). idbi federal life insurance co ltd. Retrieved July 2019, from slideshare.net: https://www.slideshare.net/ani261090/idbifederal-life-insurance-co-ltd 